\title{
A MACABRA TRÍADE DE NOITE NA TAVERNA: MULHER, AMOR E MORTE
}

Paulo Alex Soura*

RESUMO: Este texto tem como corpus a obra Noite na taverna, do escritor Álvares de Azevedo, um dos maiores escritores do Romantismo brasileiro. O foco da análise é a relação entre três elementos recorrentes em toda a obra, a saber, a figura da mulher, o amor e a morte, mostrando que os três estão intrinsicamente ligados na obra, cuja influência da literatura romântica europeia é também apontada. Para isso, nosso principal interlocutor teórico e crítico é o italiano Mario Praz, a partir de seu livro A carne, a morte e o diabo na literatura romântica.

PALAVRAS-CHAVE: Romantismo; Álvares de Azevedo; Mulher; Amor; Morte.

\section{Introdução}

A nova sensibilidade - que se delineava já na segunda metade do século XVIII, direcionada a dar vazão à imaginação e aos sentimentos arrebatadores da razão - e o espírito atormentado do romantismo entrelaçaram de maneira sui generis três potentes elementos: a mulher, o amor e a morte. Chamamo-nos potentes porque adquirem uma força descomunal nas melhores páginas do ultrarromantismo - apropriadamente chamado também de "mal-doséculo" - numa palavra, são potências descontroladas e descontroladoras da mente do homem e da mulher.

Em Noite na taverna, de Álvares de Azevedo, esses três elementos se fazem presente de modo avassalador e entrelaçado. Com exceção do conto "Johann", no qual o narrador se envolve com uma mulher não por paixão ou fascínio, mas unicamente por sua índole devassa, nas demais histórias narradas pelos personagens há mulheres belas que fascinam e enlouquecem o homem; em todas há uma forte paixão sempre violadora das normas e convenções sociais, apresentando-se como fatalidade, ou seja, um mal irremediável. Em todas, a morte faz-se um lugar-comum, seja como um fim para aqueles que cruzam o caminho dos

\footnotetext{
* Doutorando em Literatura Comparada pela Universidade Federal Fluminense (UFF). Mestre em Literatura Brasileira e Teorias da Literatura pela mesma Instituição.
} 
rapazes malditos, seja na forma de ideias mórbidas, o tema da morte é explorado à exaustão. Para se ter ideia de sua banalidade em Noite na Taverna, mencionamos o episódio no qual o personagem Bertram, involuntariamente, afoga aquele que o socorria: "apertei aquele que me socorria; fiz tanto, em uma palavra, que, sem querê-lo, matei-o" (AZEVEDO, 2001, p. $40^{1}$ ).

A medida que desenvolvemos a análise desses três componentes, tocaremos em outros assuntos que apresentam ligação com eles e que contribuem para mostrar a riqueza da obra. A análise se deterá sobre cada conto que compõe a obra.

\section{As mulheres fatais e as criaturas pálidas de Álvares de Azevedo}

\section{Solfieri}

Em uma noite, passeando pelas ruas, Solfieri vê numa janela uma mulher que canta e derrama lágrimas. Daí a pouco a mulher sai e ele a segue até ao cemitério; adormece aí e acorda febril, no outro dia, após uma noite de chuva, frio e sonhos da qual não consegue se esquecer. A imagem que fica martelando em sua mente é a do anjo do cemitério. Um ano depois, sai de uma orgia com a condessa Bárbara e, embriagado, chega a um templo. Lá, encontra um caixão, com uma falsa defunta, que ele passa a considerar como aquele anjo do cemitério. Ele a retira do caixão e a estupra no templo. Para seu espanto, a moça não estava morta, e sim em estado de catalepsia (doença que se caracteriza pelo enrijamento dos membros, insensibilidade, respiração e pulso lentos, e palidez cutânea). Ela acorda e desmaia novamente; Solfieri então a leva para casa, onde ela morre "depois de duas noites e dois dias de delírio" (NT, p. 27). O narrador cava um túmulo no quarto, coloca a defunta e cobre a sepultura com sua cama. Depois, encomenda uma estátua de cera da mulher.

A figura feminina merece uma análise mais detida por apresentar um aspecto que a distingue de outras mulheres do texto, esse aspecto é o seu caráter de Mulher Fatal. Em Noite na Taverna não há muitas mulheres fatais, na verdade, as personagens femininas nessa obra somente mantêm pontos de contato com a imagem consagrada da mulher fatal. Cremos que a explicação para tal ocorrência possa ser extraída da principal influência sobre Álvares de Azevedo, que foi Byron. Esse se esmerou na fixação do homem fatal, rebelde e conquistador; assim, só se pode imaginar que nosso escritor, ao confeccionar seu livro de contos, tinha a poderosa sombra dos heróis byronianos, não fazendo mais do que prosseguir nas pegadas do mestre. Sobre essa questão, vale ter em mente as palavras de Praz (1996, p. 181): “até cerca da metade do século XIX, há muitas mulheres fatais na literatura, mas não existe o tipo

1 Todas as citações de Noite na taverna serão dessa edição, e, para melhor fluidez da leitura, a partir desse ponto, nas citações, serão informadas apenas uma abreviação do nome da obra em itálico e a página (ex.: NT, p. 103). 
da mulher fatal do mesmo modo que existe o tipo do herói byroniano". Ou seja, tanto um quanto o outro, são figuras literárias presentes no romantismo, porém, ao segundo, foi concedido mais dedicação e acabamento por certos autores, o que resultou numa imagem com maior fixidez na história do romantismo, transformando-se mesmo em um tipo que exerceu notável predomínio na literatura romântica.

Sobre a Mulher Fatal, nos fala Praz:

O fascínio da bela mulher defunta, espécie das grandes cortesãs, das rainhas luxuriosas, das famosas pecadoras, [...] sugerirá aos românticos, provavelmente sob influência da lenda vampírica, a figura da Mulher Fatal que encarna, de tanto em tanto, em todos os tempos e todos os países, um arquétipo que reúne em si todas as seduções, todos os vícios e todas as volúpias. (PRAZ, 1996, p. 196)

Essa imagem, portanto, constituiria um arquétipo universal carregado de características comuns, reconhecíveis em tempos e locais diferentes, mas, em termos gerais, a mulher fatal detém um inerente poder de sedução sobre o homem; sua presença fascina, seu corpo é objeto de desejo, ela é um ídolo a ser adorado. Além disso, outras características lhe são presentes, tais como frieza, crueldade, arrogância, altivez, morte, etc.

Embora a mulher no conto em questão não tenha uma atitude ou ação qualquer, sendo totalmente passiva, ela apresenta traços de fatalidade, como o fascínio que desperta no personagem: por somente aparecer na janela de sua casa, ela desperta a atenção de Solfieri; por ela, ele adormece em um cemitério e profana um templo num ato sexual. Aos olhos dele, ela é um ídolo que, na sua fixidez de cataléptica ou de morta, emana uma força sedutora. Sua palidez funciona como um ímã: “A face daquela mulher era como a de uma estátua pálida à lua" (NT, p. 20). E mais à frente: "Meus olhos nunca me tinham evocado uma estátua tão perfeita. Era mesmo uma estátua: tão branca era ela" (NT, p. 23). O canto que ela entoa é um chamado aos ouvidos de Solfieri: "Não era só uma voz melodiosa: havia naquele cantar um como choro de frenesi, um como gemer de insânia" (NT, p. 20).

A predileção pelo macabro foi uma tônica da época e tem ramificação no conceito de beleza que vigorou no romantismo. Este, pouco a pouco foi fazendo de tudo o que é horrível e terrível, não meros temas para serem relatados ou descritos à distância no palco do estilo, mas verdadeiros objetos de prazer: "A descoberta do horror como fonte de deleite e de beleza terminou por agir sobre o conceito de beleza: o horrível, na categoria do belo, terminou por se tornar um dos elementos próprios do belo: do belamente horrível se passou, em graus insensíveis, ao horrivelmente belo" (PRAZ, 1996, p. 45).

Dessa primeira mudança, resultou uma variedade de estímulos para a sensibilidade romântica, entre eles, o que une morte e beleza. O espírito romântico considerava como fonte 
de beleza e de volúpia aquilo que trouxesse a marca inseparável da morte: “Tão irmãs, na verdade, para os românticos, que se fundem num só hermes bifronte de beleza fatal, íncito de corrupção e de melancolia, beleza da qual quanto mais copioso brota o gozo, tanto mais o gosto dele é carregado de amargura" (PRAZ, 1996, p. 49). Como é notório, essa personagem que fascina Solfieri traz consigo a presença inalienável da morte. Nesse conto não há um assassinato como nos demais, a morte aí aparece, primeiramente, como um estado - a catalepsia -, para depois se consumar com a morte definitiva da personagem de maneira não explicada. Da parte do protagonista-narrador, o tema vem pelo seu gosto mórbido, pois ele é um necrófilo, ou seja, sente atração sexual por cadáveres. Ao encontrar a moça dentro do caixão no templo, não pensa duas vezes: “Tomei-a no colo. Preguei-lhe mil beijos nos lábios. Ela era bela assim: rasguei-lhe o sudário, despi-lhe o véu e a capela como o noivo os despe à noiva. [...] O gozo foi fervoroso - cevei em perdição aquela vigília” (NT, p. 23).

A ligação erótica e emocional de Solfieri com a mulher defunta era tamanha, que se materializa de três formas distintas: o enterro da mulher debaixo de seu leito; a reprodução dela em estátua de cera; e a grinalda de flores murchas e secas, que traz desde então ao pescoço como um amuleto, mostrando-a aos companheiros que haviam duvidado de sua história macabra. Três maneiras diferentes de expressar a mesma finalidade: preservar a imagem e a lembrança da mulher que em sua condição de morta lhe arrebatou os sentidos.

\section{Bertram}

Nesse conto, três mulheres se envolvem com o narrador da história. Falaremos de duas aqui, enquanto a outra será tratada em outro momento. A primeira tem um nome que inspira a pureza de um anjo, Ângela, natural de Cadiz, Espanha. Aqui, já vemos o primeiro indício de filiação desta personagem à imagem recorrente no Romantismo da mulher fatal espanhola, conforme atesta Mario Praz (1996, p. 251): “Os românticos não descobriram nem inventaram a sua Espanha. Apenas concretizaram em obras de arte uma tradição e um mito para o qual colaboraram os viajantes dos dois séculos".

Para melhor compreensão, convém trazer a lume um paralelo, qual seja, a Ângela de antes e de depois da fatalidade que se abate sobre o casal. Primeiramente, o narrador a descreve como uma donzela, "linda daquele moreno das andaluzas que não há vê-las sob as franjas da mantilha acetinada [...] sem delirar sonhos delas por longas noites ardentes!” (NT, p. 32). Nesse momento Ângela é uma criatura pálida e pura, inspiradora de sonhos. Depois da separação forçada do casal (o moribundo pai de Bertram o chamara à Dinamarca para vêlo por uma última vez), tem-se o reencontro. Agora, porém, ela está casada e tem um filho, 
o que não impede os encontros dos amantes, logo descobertos pelo marido de Ângela. Bertram narra o que acontecera certa noite, quando fora chamado pela amada a entrar em sua casa; a fisionomia dela no momento salta aos olhos do observador: "eu esperava ver passar nas cortinas brancas a sombra do anjo. Quando passei, uma voz chamou-me. Entrei - Ângela com os pés nus, o vestido solto, o cabelo desgrenhado e os olhos ardentes tomou-me pela mão...” (NT, p. 35). Embora concisa, a descrição é categórica. A aura de pureza desapareceu por completo, a mudança foi da água para o vinho, bem ao gosto romântico: de criatura pálida passou a mulher-fatal. Ângela agora personifica a própria loucura, contudo, sua loucura não é desesperada, porém, fria e cruel. A mulher conduz Bertram até uma sala escura e vai buscar uma luz, para mostrar-lhe a cena perturbadora:

\footnotetext{
Quando Ângela veio com a luz, eu vi... Era horrível. O marido estava degolado. Era uma estátua de gesso lavada em sangue... Sobre o peito do assassinado estava uma criança de bruços. Ela ergueu-a pelos cabelos. Estava morta também: o sangue que corria das veias rotas de seu peito se misturava com o do pai! - Vês, Bertram, esse era o meu presente: agora será, negro embora, um sonho do meu passado. Sou tua e tua só. Foi por ti que tive força bastante para tanto crime... Vem, tudo está pronto, fujamos. A nós o futuro! (NT, p. 36-37)
}

À força do sentimento que nutria por Bertram, Ângela faz-se uma mulher diabólica, assassina do marido e do filho. É uma criminosa ensandecida e de enorme sadismo, que sacode os cabelos negros e ri diante da pergunta de Bertram sobre o sangue em suas mãos. Não sabemos se Álvares de Azevedo leu Martyrs de Chateabriand (1768-1848), mas essa descrição lembra a personagem Velléda (uma maga patriótica, incitadora da resistência contra o estrangeiro); na citação de Praz da obra de Chateabriand, há até uma referência à degolação, tal como Ângela fizera ao marido.

Ângela traz outros atributos da mulher fatal. No início da narrativa, Bertram anuncia que contará a história da mulher que o levou à perdição, que o iniciou no sexo, na bebida e no jogo, que o levou a matar em duelo, num único dia, seus três melhores amigos. O jovem consumido de paixão se entrega completamente à mulher amada e aos impulsos de prazer e de ódio, a que ela, a mulher dominante, o conduz. Depois do duplo homicídio, eles fogem e passam um tempo juntos, porém, um dia ela parte numa demonstração da liberdade pessoal que toda mulher fatal possui. O homem é quem fica preso a ela ou à sua lembrança, como Bertram declara: "Um dia ela partiu: partiu, mas deixou-me os lábios ainda queimados dos seus, e o coração cheio de gérmen de vícios que ela aí lançara. Partiu. Mas sua lembrança ficou como o fantasma de um mau anjo perto de meu leito" (NT, p. 38).

Depois de Ângela tê-lo deixado, Bertram torna-se de vez um celerado, experimentando outras peripécias; até que um dia, na Itália, saciado da vida boêmia, decide suicidar-se 
atirando-se de um rochedo; não morre, pois fora salvo pelos tripulantes de uma corveta. A partir daqui, desenrolam-se alguns dos pontos altos de todo o livro. É como tripulante da embarcação que ele conhece e se envolve com outra mulher, qual seja, a "mulher do comandante", tratada no conto por este epíteto. Ela personifica uma imagem poética de fato muito cara a Álvares de Azevedo, como aponta Antonio Candido (1975, p. 186): "É muito dele a imagem da donzela, adormecida ou não, na praia tenebrosa, molhada pelas ondas". Eis a primeira referência à mulher do comandante em: "Criatura pálida, parecera a um poeta $\mathrm{O}$ anjo da esperança adormecendo esquecido entre as ondas” (NT, p. 42). A criatura pálida trata-se de uma imagem única que perpassa toda a sua poesia, resvalando também nesses contos. Sempre envolta numa atmosfera de sonho e em associação com elementos naturais, a mulher pálida, bela, frágil e de aspecto divino, é figura marcante em toda a obra azevediana.

A mulher do comandante apresenta ainda uma característica particular: a melancolia. A referência textual não passa de uma nota descritiva que apenas toca no tema sem, contudo, aprofundar ou fixar a imagem. Porém, é suficiente para demonstrar a atenção do jovem autor nos reconhecidos moldes europeus, visto que "está por toda a literatura, do romantismo ao nosso tempo, uma insistência sobre essa inseparabilidade do prazer da dor, em teoria; e, na prática, uma pesquisa dos temas de beleza atormentada e contaminada" (PRAZ, 1996, p. 46). A melancolia da personagem faz-nos, novamente, remeter ao ideal de beleza tratado mais acima, pois outra associação estabelecida pelo gosto atormentado dos românticos é aquela que ligou a beleza à tristeza e ao sofrimento. Sobre a personagem, descreve o narrador: " $E$ ela - ela no meio de sua melancolia, de sua tristeza e sua palidez - ela sorria às vezes quando cismava sozinha - mas era um sorrir tão triste que doía” (NT, p. 43-44). Esse estado atraía a Bertram, que confessa ter-lhe escrito versos, como um poeta o faz à sua musa.

Um dos grandes nomes do pós-romantismo europeu, que foi Charles Baudelaire (1821-1867), tem uma exposição categórica sobre a junção daqueles dois motivos:

Encontrei a definição do Belo, de meu Belo.

É algo ardente e triste... uma fronte sedutora e bela, uma fronte feminina, quero dizer, é uma fronte que faz sonhar ao mesmo tempo [...] com a volúpia e com a tristeza; que comporta uma ideia de melancolia, de lassidão, de saciedade mesmo - ou uma ideia contrária, isto é, um ardor, um desejo de viver, associados a uma amargura recorrente, como vindas da privação e da desesperança. (...)

Eu não pretendo que o prazer não possa se associar com o Belo, mas digo que o prazer é um dos ornamentos mais vulgares, enquanto a Melancolia é, por assim dizer, a ilustre companhia do Belo, a ponto que eu não concebo absolutamente (meu cérebro seria um espelho encantado?) um tipo de Belo onde não haja a Infelicidade (BAUDELAIRE apud PRAZ, 1996, p. 47). 
Álvares de Azevedo, ao compor essa personagem palidamente bela e melancólica, parece antecipar aquilo que Baudelaire anos mais tarde iria dizer. O poeta europeu fala em ardência e tristeza, numa fronte feminina sedutora e bela, que comporta ideias contrárias de melancolia e ardor, de lassidão e desejo de viver. Agora, observemos o efeito que a mulher do comandante proporciona em Bertram: "Aquela mulher me enlouquecia as noites. Era como uma vida nova que nascia cheia de desejos, quando eu cria que todos eles eram mortos como crianças afogadas em sangue ao nascer”. (NT, p. 44). Não só o amor puro, mas também aquele nascido de uma relação adulterina tem seu "fogo que arde sem se ver", e essa ardência, Bertram a sentiu de forma arrebatadora, como fica patente na passagem da batalha marítima entre a corveta e um navio pirata. Enquanto os marinheiros lutavam como feras, enquanto o mar enchia-se de cadáveres, diz nosso protagonista: "o comandante se batia como um bravo, eu o desonrava como um covarde" (NT, p. 47). E acrescenta uma interpretação do episódio com uma imagem forte, expressa de maneira ritmada e rimada: "Foi uma visão de gozos malditos - eram os amores de Satã e de Eloá, da morte e da vida, no leito do mar” (NT, p. 47). Que a relação com a mulher do comandante faz arder uma nova vida em Bertram, já dissemos, resta agora verificar como essa relação entre os dois amantes versa com o tema da morte, como aponta a polarização acima.

Depois da batalha entre os navios, a corveta encalhou num banco de areia e todos os tripulantes que restaram ficaram numa jangada; uma tempestade no meio do mar veio colher outros muitos marujos. Ao amanhecer, eram cinco pessoas, Bertram, o comandante, a sua esposa, e dois marinheiros. Dois dias depois, restavam apenas o comandante, a mulher e nosso narrador. A partir desse ponto da narrativa, os três personagens conviverão mais tragicamente com a iminência da morte carregada de desespero e horror, em virtude de dois fatos, a sede e a fome: "um fato velho e batido, uma prática do mar, uma lei do naufrágio a antropofagia" (NT, p. 57). Os três tiram a sorte para saber quem morreria primeiro, quem serviria de alimento para os outros dois, e como era de se prever, o comandante foi o desafortunado. Ele resiste por mais um dia, chora, suplica, até que decide lutar contra Bertram, que o mata sufocando-o com o pé na garganta. O que se segue, o narrador resume numa frase: “Aquele cadáver foi nosso alimento dois dias...” (NT, p. 60). Os dois amantes partilham agora a carne do homem que fora marido dela e amigo acolhedor para ele. Restando os dois somente na jangada, o final não é totalmente surpreendente. Os dois têm uma última relação sexual, e a mulher enlouquece, tornando-se perigosa à Bertram, que a mata sufocada. Uma onda arrasta o cadáver; Bertram desmaia e só acorda num navio inglês. 


\section{Gennaro}

De modo geral, é um dos contos menos empolgantes. Todas as personagens, incluindo o protagonista, não são trabalhadas com o mesmo cuidado demonstrado em outras: a diferença de profundidade psicológica entre Gennaro e Bertram é gritante, pois este, como vimos, é o ápice do super-homem byroniano no livro, enquanto aquele, em muitos momentos, chega ser o seu oposto: frágil, dócil, medroso e amante verdadeiro. Isso faz com que o conto seja, por assim dizer, um pouco desalinhado em relação ao espírito do livro, a linha mestra, ou seja, a vertente mal-do-século.

No conto "Gennaro", são duas as mulheres que se envolvem com o narrador: Laura e Nauza. Ambas são "belas como duas visões de luz" (NT, p. 66), ou seja, não passam de mais duas criaturas pálidas sem vigor ou algo que as particularizem. Laura "Era uma moça pálida, de cabelos castanhos e olhos azulados; sua tez era branca, e só às vezes, quando o pejo a incendiava, duas rosas lhe avermelhavam a face e se destacavam no fundo de mármore" (NT, p. 67). Quanto à Nauza, não há descrições de sua constituição física, só sabemos que tem vinte anos e servia de modelo de pintura para Godofredo Walsh, com quem se casou.

Podemos dizer que as duas mulheres sequer são variações sobre um mesmo tema. Como em todas as narrativas, a importância delas vem pela relação que mantêm com o narrador, no entanto, nesta não se nota uma imagem, ou melhor, uma presença mais nítida das mulheres, por serem poucas as ações e inexpressivas as falas delas.

Como nos outros contos, nesse também o amor-paixão é transgressor das normas sociais: Gennaro ama Nauza e ela a ele, entretanto, o amor deles, nesse primeiro momento, é platônico: "Amei-a, mas meu amor era puro como meus sonhos de dezoito anos. Nauza também me amava: era um sentir tão puro! era uma emoção solitária e perfumosa como as primaveras cheias de flores e de brisas que nos embalavam aos céus da Itália (NT, p. 67). No entanto, a primeira com quem Gennaro se relaciona de fato é a filha de Walsh. É ela também a primeira vítima do rastro de infelicidade que os homens azevedianos, descendentes dos homens fatais de Byron, trazem consigo. Laura não passa de uma menina pura com seus "risos, seus beijos de criança de quinze anos". Uma manhã em que Godofredo e Nauza haviam saído, ela vai até ao quarto de Gennaro, que dormia, e deita-se ao seu lado. Ele não resiste àquela tentação e se relaciona sexualmente com Laura, que passa a visitá-lo em seu quarto todas as manhãs, por três meses. O calvário de Laura começa quando ela descobre que está grávida. Pede a Gennaro que se case, mas ele nega. A moça então começa a definhar, seu sorriso se torna frio e sua palidez natural se acentua, vindo a morrer no seu leito, em delírio e perturbação: 
— Gennaro, eu te perdôo: eu te perdôo tudo... Eras um infame... Morrerei... Fui uma louca... Morrerem... por tua causa... teu filho... o meu... vou vê-lo ainda... mas no céu... Meu filho que matei... antes de nascer...

Deu um grito: estendeu convulsivamente os braços como para repelir uma idéia, passou a mão pelos lábios como para enxugar as últimas gotas de uma bebida, estorceu-se no leito, lívida, fria, banhada de suor gelado, e arquejou... Era o último suspiro. (NT, p. 71)

Bem ao gosto romântico, a patética imagem do moribundo que definha numa cama até morrer em desespero, faz-se presente em todo o romantismo, como reflexo da mentalidade mórbida e trágica que faz da hora da morte, uma encenação a um só tempo estúpida e desesperada. Mas de qualquer forma, a imagem serve para ressaltar a força descomunal que a morte adquire nas páginas da vertente mal-do-século do romantismo, cuja índole fazia sofrer e morrer as mais puras personagens. Laura é uma vítima impotente dessa força que a abate depois da ação de outra, a do amor. Este é o fato primeiro que dá origem a todos os conflitos das histórias, pois é, como já falamos, transgressor por princípio. Mas antes dela ser feita vítima, ela mesma fez uma vítima ao declarar, em meio ao delírio, o aborto cometido: é o vezo da morte rasgando fundo a vida das personagens.

A transgressão continua ainda mais desafiadora. Com a morte da filha, Godofredo parece enlouquecer: "Todas as noites fechava-se no quarto onde morrera Laura: levava aí a noite toda em solidão" (NT, p. 71), mas não dormia, ora andava de um lado para o outro do quarto, ora chorava, ora ficava em silêncio. A situação estava criada para Gennaro concretizar o amor que nutria pela esposa do velho pintor. Uma noite - em mais uma cena de romantismo exacerbado - ele declara seu amor a Nauza, que entre lágrimas e soluços também confessa o seu por ele, e o desfecho só poderia ser um: "E as noites que o mestre passava soluçando no leito vazio de sua filha, eu as passava no leito dele, nos braços de Nauza" (NT, p. 73).

O adultério praticado no quarto ao lado é logo descoberto por Godofredo, que à princípio não parece se importar muito, mas decide se vingar matando, primeiro, Gennaro, depois a esposa, e a si mesmo. Depois de ser quase morto pelo velho, que o fez precipitar-se de um despenhadeiro, Gennaro volta para a casa do mestre com o intuito de se vingar, mas a cena que encontra é terrível: Nauza e Godofredo mortos envenenados por um pó branco adquirido pelo velho:

Ergui os cabelos da mulher, levantei-lhe a cabeça. Era Nauza, mas Nauza cadáver, já desbotada pela podridão. Não era aquela estátua alvíssima de outrora, as faces macias e colo de neve... Era um corpo amarelo... Levantei uma ponta da capa de outro: o corpo caiu de bruços com a cabeça para baixo; ressoou no pavimento o estalo do crânio. Era o velho!... morto também e roxo e apodrecido: eu o vi: da boca lhe corria uma escuma esverdeada (NT, p. 82). 
Assim como Laura, Nauza é mais uma criatura pálida que morre depois de amar e se envolver com o homem-fatal romântico. De uma forma ou de outra, a desgraça e a morte surgem como um destino certo e fatídico para elas. $\mathrm{O}$ trecho acima é significativo porque demonstra a capacidade de Álvares de descrever situações não apenas lúgubres, mas repugnantes mesmo, quer dizer, um autor notabilizado pelas descrições de suas mulheres-anjos, belas e puras, coloca em cena agora dois cadáveres: um amarelo e podre, outro, roxo e igualmente podre, do qual escorria da boca um muco esverdeado. É uma cena bem alinhada a essa estética do horror que foi o ultrarromantismo, com seu gosto pelo grotesco e pelo repugnante. Esse conto explora superficialmente um tema muito desenvolvido no romantismo europeu, a agnição, que é um termo mais relacionado mesmo ao literário e ao gênero dramático, especificamente; significa, lato sensu, a ação por parte dos personagens de uma obra de conhecer os laços de parentesco que existem entre si. Mario Praz toca nesse assunto ao afirmar que

a velha agnição do romance grego é um arrimo do romance gótico, como o será do romantismo em geral: pais que encontram os filhos nas circunstâncias mais dramáticas, eis a grande mola das peças teatrais e dos romances por volta de 1830. É Buridan que descobre em Gaultier e Philippe os filhos tidos com Marguerite de Bourgogne, filhos de Margherita e também seus amantes (La tour de Nesle, de Dumas); é Gennaro, o filho incestuoso de Lucrécia Bórgia que se crê amado de um odioso amor pela mulher monstruosa em que ele descobrirá sua mãe e que ele matará (Lucrèce Borgia, de Victor Hugo) [...]: eis alguns exemplos mais conhecidos de uma fórmula que era cara aos românticos também pelo sabor de incesto que se podia extrair dela. (PRAZ, 1996, p. 117)

A longa citação é elucidativa porque aponta, primeiro, a ligação entre a agnição de que falamos e a morte: filhos que matam os pais e vice-versa; segundo, o aspecto incestuoso desse motivo; e terceiro, o possível exemplo no qual o autor foi buscar o nome de seu personagem: o Gennaro de Hugo é filho bastardo de Lucrécia Bórgia, o Gennaro de nosso autor é uma espécie de filho adotivo de Godofredo, seu mestre, em ambos os casos podemos ver uma afinidade.

Além disso, a relação de Nauza com Godofredo também toca de leve nesse motivo. Sobre o casamento dos dois, diz-nos o narrador do conto: "diziam uns que este casamento fora um amor artístico por aquela beleza romana, como que feita ao molde das belezas antigas; outros criam-no compaixão pela pobre moça que vivia de servir de modelo. O fato é que ele a queria como filha, como Laura" (NT, p. 66). Lembramos que ao descobrir os amantes em seu quarto, Godofredo Walsh não fez mais que arrastar Gennaro para o quarto da filha, a fim de mostrar-lhe o quadro que pintara, e no outro dia, ao conversar com o rapaz, não tocou no caso do adultério, isto é, não lhe veio a mínima raiva pelo fato de ser traído. 
Essa indiferença parece confirmar a afirmação de Gennaro, de que a relação deles está mais para pai e filha do que para esposo e esposa. E, se no romance de Victor Hugo, Lucrécia é morta pelo seu filho Gennaro, no conto de Álvares de Azevedo é o "filho" Gennaro que quase é morto pelo "pai”, e a "filha” Laura é assassinada por Godofredo. Tais fatos também deixam patente a ligação entre agnição e morte. Todavia, tanto entre Godofredo e Gennaro, quanto entre Godofredo e Nauza, é óbvio que não se trata, objetivamente, de relação entre pai e filho, porém, apenas de uma aproximação. Por isso, dissemos mais acima, que só superficialmente o conto tematiza a agnição romântica.

\section{Claudius Hermann}

No conto narrado por Claudius Hermann, é a amazona Eleonora que incorpora um motivo diferente dos demais. À primeira vista, ela é apresentada como uma verdadeira mulher fatal, vejamos o porquê. O cenário é um hipódromo, o protagonista, um viciado em apostas. A entrada de Eleonora causa um rebuliço no público: "um murmúrio correu pelas multidões, um sorriso... e depois eram as frontes que se expandiam, e depois uma mulher passou a cavalo" (NT, p. 87). É a primeira vez que Claudius a vê, e se na platéia causou pelo menos curiosidade, nele o efeito foi ainda mais forte, vertendo-se em completo fascínio:

\footnotetext{
Víssei-la como eu, no cavalo negro, com as roupas de veludo, as faces vivas, o olhar ardente entre o desdém dos cílios, transluzindo a rainha em todo aquele edema soberbo: víssei-la bela na sua beleza plástica e harmônica, linda nas suas cores puras e acetinadas, nos cabelos negros, e a tez branca da fronte; o oval das faces coradas, o fogo de nácar dos lábios finos, o esmero do colo ressaltando nas roupas de amazona: víssei-la assim, e à fé, senhores, que não havíeis de rir de escárnio como rides agora! (NT, p. 87)
}

Do alto de seu cavalo negro, Eleonora é um ídolo fascinante, de face viva e branca, de olhar ardente, uma rainha desdenhosa e soberba; sua beleza é plástica e harmônica, talvez porque meticulosamente composta e artificial; seus lábios finos possuem um fogo brihante e colorido, enfim, todas as características de uma mulher fatal. Entretanto, Eleonora não é, absolutamente, uma mulher fatal, e sim mais uma criatura pálida personificadora de mais um motivo do romantismo, qual seja, o motivo da dama perseguida. No capítulo terceiro de seu livro, Mario Praz fala do tema, ao mesmo tempo em que aponta em qual autor e em que livro, foi Álvares de Azevedo se espelhar:

A jovenzinha infeliz e perseguida! O tema é tão velho quanto o mundo, mas no século XVIII foi refrescado por Richardson com a celebérrima Clarrissa Harlowe, a donzela de grande virtude e beleza que, assediada e seduzida pelo libertino 
Lovelace, perseguida por implacáveis parentes, [...] fenece lentissimamente entre os aparatos fúnebres de uma morte exemplar. (PRAZ, 1996, p. 102)

O romance inglês leva o nome de sua protagonista, Clarissa Harlowe, o ano de sua publicação é 1747 , e segundo o mesmo crítico, quanto a esse motivo o livro serviu de modelo para todos os romances posteriores. Em nosso conto, encontramos uma prova cabal de que Álvares de Azevedo conhecia o romance de Samuel Richardson (1689-1761), já que pôs na boca de Claudius Hermann, que discutia com seus companheiros, estas palavras:

— Ride, sim! misérrimos! que não compreendeis o que porventura vai de incêndio por aqueles lábios de Lovelace (...). Insano, que nunca sonhastes Lovelace sem sua máscara, talvez chorando Clarisse Harlowe, pobre anjo, cujas asas brancas ele ia desbotar maldizendo essa fatalidade que fez do amor uma infâmia e um crime. (NT, p. 87-88)

Se esse fato já indica a filiação, a análise do enredo do conto mostra, sem sombra de dúvida, que "Claudius Hermann" é um decalque em miniatura do romance inglês. É lamentável não termos o romance à mão para aprofundarmos na comparação textual, mas cremos que as indicações de Praz sejam suficientes: "Lovelace se gaba da sua conduta celerada, comporta-se como libertino sem escrúpulos (...), sequestra Clarissa e a coloca numa casa de tolerância, violenta-a depois de narcotizá-la e, ao mesmo tempo, professa seu amor por ela e declara querer esposá-la” (PRAZ, 1996, p. 103).

Numa noite depois de um baile, a duquesa Eleonora dormia num divã, Claudius havia subornado um criado para conseguir a chave do aposento da duquesa; ele a leva para o quarto, coloca num copo de vinho uma substância e dá de beber à mulher. Tal como o libertino Lovelace, o narrador do nosso conto dopa a mulher que deseja possuir, pois o líquido era um narcótico, no qual havia "algumas gotas daqueles licores excitantes que acordam a febre nas faces e o desejo voluptuosos no seio" (NT, p. 93). A droga não era só para fazer domir, mas também para estimular a libido da mulher, pois como o personagem do romance francês, Claudius abusa sexualmente de Eleonora enquanto ela dorme. Mas como se excita alguém que dorme? Reflexo da intensidade da imaginação romântica.

Claudius Hermann repete a façanha da mesma maneira: depois dum baile, ele entra no quarto, coloca o narcótico num copo com água, a mulher entra acompanhada dessa vez por seu marido, o duque Maffio; ambos bebem a água do copo, o duque sai, ela despe-se e coloca apenas um véu, quando o licor começa a fazer efeito. Novamente aqui, o decalque: Claudius rapta Elenora numa carruagem como Lovelace raptara Clarissa, e, como esta, a duquesa é levada para uma casa, no conto, para uma estalagem. Aí, ele encena uma das imagens mais caras de todo o romantismo: o homem apaixonado em seu ato de vassalagem amorosa: 
“estávamos sós, o homem e seu anjo, e a criatura da terra ajoelhou-se ao pé do leito da criatura do céu" (NT, p. 99). Por fim, ela acorda e desespera-se por tudo aquilo, interroga a seu raptor, que começa a lhe contar sua história de devasso arrependido por causa da paixão por uma mulher, que é ela: "O libertino amou pois o anjo, voltou o rosto ao passado, despiuse dele como de um manto impuro" (NT, p. 104). Ele declara seu amor obsessivo por ela, convida a fugir com ele, como igualmente Lovelace fez.

Durante esses episódios, Eleonora não é mais retratada como uma mulher de poder fascinante e fatal, como a primeira imagem sugere; agora, abundam as descrições e comparações que fazem dela somente uma criatura pálida, somente mais um anjo de seio palpitante, forma suave e estatutária, uma donzela lânguida e pura. A isso, juntemos uma característica da donzela perseguida de Richardson, encontrda também em Eleonora. Segundo Praz, o autor inglês "mostra a moça como piedoso cordeiro entre lobos rapaces, numa casa de má fama e numa prisão de devedores, e, enfim, sobre o leito de morte, a dizer sua última vontade, a perdoar todos” (PRAZ, 1996, p. 102). Assim como Clarissa, a duquesa Eleonora a todo momento mostra seu caráter virtuoso: “- Meu Deus! meu Deus! por que tanta infâmia, tanto lodo sobre mim? Ó minha Madona! por que maldissestes minha vida, por que deixastes cair na minha cabeça uma nódoa tão negra?” (NT, p. 106). Também como a personagem do romance francês, Eleonora dá exemplo de piedade cristã para com o seu algoz: " - Matai-me então! não tereis um punhal? Uma punhalada pelo amor de Deus! Eu juro, eu vos abençoarei...” (NT, p. 108).

Finalmente o narrador convence sua vítima de que fugir com ele é inevitável, já que Eleonora não poderia retornar para casa, nem continuar sua vida normalmente, sem ser estigmatizada de adúltera. No final do conto, Claudius pára de contar a história - "uma força invencível o prendia" - e um companheiro seu, Arnold, incumbe-se de continuar:

\footnotetext{
Um dia Claudius entrou em casa. Encontrou o leito ensopado de sangue e num recanto escuro da alcova um doido abraçado com um cadáver. O cadáver era $\mathrm{O}$ de Eleonora: o doido nem o pudéreis conhecer tanto a agonia o desfigurava. Era uma cabeça hirta e desgrenhada, uma tez esverdeada, uns olhos fundos e baços onde o lume da insânia cintilava a furto como a emanação luminosa dos pauis entre as trevas... (NT, p. 118-119)
}

Como é uma verdadeira fixação, a morte tem seu lugar guardado em todas essas histórias, e como nas anteriores, nesta, ela também é destinada à mulher. Aqui ela vem em forma de vingança: o doido a que se refere o trecho acima é o duque Maffio. Aliada à morte temos a loucura, que acomete o marido traído, marcando-lhe terrivelmente a aparência: 
cabeça imóvel e bagunçada, a pele verde e os olhos continham um luz similar ao fogo-fátuo dos pântanos.

Mas por que Eleonora é perseguida e assassinada se não passa de uma vítima sem dolo? Segundo Praz, tal procedimento tem por trás de si a lógica da "filosofia" do Marquês de Sade: "O sucesso do motivo da perseguida entre os escritores do século XIX é especialmente devido a razões que impuseram a obra do Divino Marquês, e não as que fizeram Richardson escrever Clarissa" (PRAZ, 1996, p. 111). Resumidamente, o pensamento sadiano postula que “a virtude leva à miséria e à ruína, e o vício à prosperidade” (PRAZ, 1996, p. 105). De acordo com essa inversão de valores, Sade valoriza o vício e a destruição, ou seja, o mal, enquanto reserva à virtude e à bondade, somente sofrimento e morte.

Não obstante, tudo indica que Álvares de Azevedo teve como molde o romance de Richardson. Coloca-se, aparentemente, uma questão: o motivo da dama perseguida em Noite na Taverna deve-se à influência de Sade ou de Richardson? Achamos que aos dois. Richardson forneceu o exemplo prático, Sade, a mentalidade, ou seja, o suporte teórico que funcionou como estimulante para a índole romântica. Além disso, lembramos que Lorde Byron foi a maior influência para Álvares de Azevedo, e aquele foi um gênio na exploração da imagem do homem fatal, que para sê-lo, obrigatoriamente, precisa de vítimas femininas.

\section{Johann / Último beijo de amor}

As duas últimas narrativas de Noite na Taverna podem ser analisadas juntas, pois se encandeiam no tempo e no conteúdo, porque a segunda só existe em consequência das ações ocorridas na primeira. Vamos aos poucos desvelando as peripécias das duas narrativas, dentro de nossa análide da figura feminina envolvida em ambas as histórias, visto que os personagens principais são os mesmos; como também a ação da morte, que faz-se ainda mais desvastadora e abrangente do que nas outras.

Em "Johann" só há uma única personagem feminina, sem nome, sem fala e nem atitude, sua relação com o protagonista é rápida e inverossímil. Num bilhar em Paris, Johann joga com um jovem chamado Artur, "uma figura loira e mimosa como a de uma donzela" (NT, p. 122). Eles se desentendem por causa de uma jogada e Johann dá uma bofetada no rapaz que lhe joga as luvas no rosto. Insulto por insulto, tem-se uma situação que só podia ser resolvida com um duelo. É o que eles decidem fazer. Passam num hotel onde Artur escreve uma carta, eles brindam, depois vão para um lugar deserto; armados de pistolas escolhidas a esmo, atiram simultaneamente, Artur cai quase morto. Johann retira o anel e duas cartas que estavam com o jovem. Numa das cartas estava escrito: “À uma hora da noite 
na rua de... n $\mathrm{n}^{\circ} 60,1^{\circ}$ andar: acharás a porta aberta. Tua G.” (NT, p. 129). A letra maiúscula abreviada aumenta o mistério já antevisto no decorrer do conto, e cuja solução encontra-se na narrativa seguinte. Trata-se, na verdade, de um bilhete de sua amada, que o esperava e de quem não se tem qualquer descrição, apenas uma menção à sua pureza. Johann lê o bilhete e tem uma idéia infame: decide ir ao encontro da jovem no lugar de Artur:

Fui à entrevista. Era no escuro. Tinha no dedo o anel que trouxera do morto... Senti uma mãozinha acetinada tomar-me pela mão, subi. A porta fechou-se. Foi uma noite deliciosa! A amante do loiro era virgem! Pobre Romeu! Pobre Julieta! Parece que essas duas crianças levavam a noite em beijos infantis e em sonhos puros! (NT, p. 130)

Quase completamente desprovida de conteúdo significativo nesse conto, sabemos contudo que a moça é virgem, ou seja, é mais uma criatura pálida a engrossar o elenco dessa personagem única. Entrentanto, um fato, ou melhor, um motivo a faz singular: o de ser irmã de Johann. Esse conto tematiza outro motivo explorado pelos românticos, a saber, o incesto, como observa Praz:

Também o incesto, já enobrecido por Prévost em Cleveland (1731), graças ao princípio do "direito divino" da paixão, será um tema caro aos românticos, especialmente a Chateaubriand, que envolve de fascínio poético e de dignidade sentimental o amor incestuoso entre irmão e irmã, elaborando, em medidas imprecisas, certos dados de sua própria vida. (PRAZ, 1996, p. 114)

Se Álvares de Azevedo, seguindo o modelo europeu, também explorou o tema, não o fez da mesma maneira que Chateaubriand, por exemplo. Segundo Praz (1996, p. 114), ao tratar da relação entre irmão e irmã amantes, o autor francês demonstra um gosto pelo aspecto transgressor que o assunto contém, juntamente com o sabor de sacrilégio, advindo pelo fato de sua personagem também ser virgem. O autor brasileiro agiu de modo diverso. Embora Johann declare - em tom voluptuoso, diga-se de passagem - que a noite com a virgem fora deliciosa, nosso autor fez seu personagem libertino lamentar profundamente o fato de ter se relacionado com a própria irmã, fazendo-o pertubar-se ao final do conto e colocando-lhe na boca estas palavras: "Na verdade que sou um maldito! (...) Vede: sinto frio, muito frio: tremo de calafrios e o suor me corre nas faces! Quero o fogo dos espíritos! a ardência do cérebro ao vapor que tontei... quero esquecer! (NT, p. 133). E ao ser interrogado sobre o que sentia, responde indignado ante a incompreensão: "O que tenho? o que tenho? não o vedes, pois? Era minha irmã!” (NT, p. 133). Cremos que a atitude de arrependimento por parte do personagem seja reflexo de uma hesitação pessoal do autor ligada a fatores externos, como a moral da época e a poderosa influência do meio familiar. 
Antonio Candido também vê a influência desses dois fatores ao falar sobre a imaginação do autor, que é "atraída pela sensualidade e ao mesmo tempo dela afastada pelo escrúpulo moral e a imagem punitiva da mãe, conduzindo a uma idealização que acarreta como contrapeso, em muitas imaginações vivazes, a nostalgia do vício e da revolta" (CANDIDO, 1975, p. 179). De acordo com o exposto, a atitude de Álvares de Azevedo traduz um balanceamento entre a intenção artística, de um lado, e as amarras da moral social e familiar, de outro. Em outras palavras, se por um lado, a nostalgia do vício como afirma o crítico e o senso estético, cunhado ao molde estrangeiro, o impeliam a ter o incesto como tema, por outro lado, a moral e a imagem materna funcionam como um atenuante para a intenção do escritor no trato do mesmo tema.

Voltando à análise da personagem feminina, passemos agora para a narrativa seguinte. Pela narração em terceira pessoa, é nos informado a cena em que se passa mais esta história macabra: é madrugada, os homens bêbados agora dormem no escuro, espalhados pelo chão da taverna. Porém, o foco da narração muda-se para a personagem que adentra:

\begin{abstract}
Uma luz raiou súbito pelas fisgas da porta. A porta abriu-se. Entrou uma mulher vestida de negro. Era pálida, e a luz de uma lanterna, que trazia erguida na mão, se derramava macilenta nas faces dela e dava-lhe um brilho singular aos olhos. Talvez que um dia fosse uma beleza típica, uma dessas imagens que fazem descorar de volúpia nos sonhos de mancebo. Mas agora com sua tez lívida, seus olhos acesos, seus lábios roxos, suas mãos de mármore, e a roupagem escura e gotejante da chuva, disséreis antes - o anjo perdido da loucura. (NT, p. 135-136)
\end{abstract}

Do ponto de vista pictórico, essa imagem pode ser eleita a que melhor representa o estilo gótico em todo o livro, pois é um fantasma de mulher. Mais que isso, a descrição tétrica ajusta-se à alegoria tradicional da ceifadora: é a própria encarnação da morte. A mulher passeia entre os libertinos, acorda a Arnold que a reconhece. Nesse momento, o leitor descobre que essa mulher é a mesma da história de Johann, a mesma com quem ele havia transado há cinco anos, ou seja, sua irmã:

— Sim: já não sou bela como há cinco anos! É verdade, meu loiro amante! É que a flor de beleza é como todas as flores. Alentai-as ao orvalho da virgindade, ao vento da pureza - e serão belas. Revolvei-as no lodo... e como os frutos que caem, mergulham nas águas do mar, cobrem-se de um invólucro impuro e salobro! Outrora era Giorgia, a virgem: mas hoje é Giorgia, a prostituta! (NT, p. 137-138)

As palavras da personagem vêm, primeiramente, confirmar a sua condição de virgem pura no conto precedente; em segundo lugar, vêm informar seu estado atual: a desonra em que caiu depois de haver se relacionado sexualmente com Johann. Assim, temos pólos contrários: de um lado, virgindade e pureza, de outro, prostituição e infâmia. Depois da 
explicação de Giorgia, é Arnold que elucida de vez a questão: ele é o Artur da narrativa anterior, o mesmo que jogava com Johann e acabou duelando com este, indo parar num hospital, em vez de morto na rua deserta, como nos faz pensar a história anterior. Aliás, algo que demonstra certa habilidade artística do autor na ligação entre as histórias e na disposição dos acontecimentos, forçando o leitor a uma leitura mais atenta.

O caso de Giorgia exemplifica de forma brilhante a "queda para o mal" e o fatalismo, tendências típicas do mal-do-século, que ganha um aditivo ainda mais rico, como veremos ao nos debruçarmos sobre a questão da morte nas duas narrativas. Antes, porém, falemos de outro motivo romântico presente em Noite na Taverna, mais exatamente neste conto. Tratase do motivo da prostituta redimida pelo amor, que de acordo com Praz, "transformar-se-á nos românticos um dos aspectos de seu culto da beleza contaminada: quantas vezes o encontraremos, desde Musset, em Rolla ('Não era sua irmã, essa prostituída?'), até o italiano crepuscular Gozzano, esse tipo de "pureza na prostituição"” (PRAZ, 1996, p. 113).

Antecipando o final, a personagem observa à Arnold/Artur que a união dos dois neste mundo seria impuro e impossível por causa do peso das convenções socias, ao mesmo tempo em que demonstra seu sentimento amoroso pelo rapaz: "na terra nosso leito seria impuro, o mundo manchou nossos corpos. O amor do libertino e da prostituta! Satã riria de nós. É no céu, quando o túmulo nos lavar em seu banho, que se levantará nossa manhã de amor" (NT, p. 138). O diálogo se dá numa atmosfera de drama crescente; ele fala dos cinco anos de agonia e saudade dela, de sua errância pelo mundo na tentativa de esquecê-la com bebedeiras e prostitutas. Os amantes choram e se beijam. Giorgia mostra Johann morto no chão. Ela tem um propósito que a todo momento expressa com falas que deixam patente um tom de resignação: “- Escuta, Artur, eu vinha só dizer-te - adeus! - da borda do meu túmulo: e depois contente fecharia eu mesma a porta dele... Artur, eu vou morrer!” (NT, p. 141).

O final dessa história reencena o final de um drama clássico de William Shakespeare (1564-1616), Romen e Julieta, já aludido duas vezes: a primeira alusão encontra-se no conto "Johann", cuja citação já fizemos aqui: está nas palavras desse personagem depois de passar a noite com Giorgia: "Pobre Romeu! Pobre Julieta"; a segunda é a epígrafe do último conto, uma citação da mesma peça do autor inglês, na qual, traduzindo, lemos: "Bem Julieta! Eu deitar-me-ei contigo esta noite". De fato, é o que se sucede. Vejamos o desenlace da última narrativa de Noite na Taverna:

A mulher recuava... recuava. O moço tomou-a nos braços, pregou os lábios nos dela. Ela deu um grito, e caiu-lhe das mãos... Era horrível de ver-se. O moço tomou o punhal, fechou os olhos, apertou-o no peito, e caiu sobre ela. Dois gemidos sufocaram-se no estrondo do baque de um corpo... (NT, p. 143) 
Como o nome do conto prenuncia, os amantes dão um último beijo selando o amor de outrora; e como a epígrafe indica, eles suicidam-se um após o outro. De certo modo, essa reencenação do final shakespeariano vem coroar o motivo da prostituta redimida pelo amor e pela morte. Por esta razão, julgamos não se tratar de uma remissão impune, mas antes, a leitura mais ajustada do episódio talvez seja aquela que aceita a remissão, mas esta só vem pela morte da personagem. O crítico Heron de Alencar, no terceiro volume da obra organizada por Afrânio Coutinho, A Literatura no Brasil, fala sobre o binômio amor e morte:

\begin{abstract}
No estudo do amor romântico, há um aspecto que merece particular atenção: é a permanente vinculação do amor à idéia da morte. E não somente à idéia ou à consciência da morte, mas, muita vez, à própria necessidade da morte. [...]

Seres apaixonados e em luta contra a sociedade injusta, saturada de preconceitos e interesses materiais, os heróis românticos não abdicam nunca do direito de serem felizes pela realização do seu amor; há neles perfeita consciência da fatalidade que espiritualmente os uniu, sentem o absurdo da vida que os leva a experimentar as maiores vicissitudes e os maiores sofrimentos, enfrentam e vencem todas as provações [...]. E quando é de todo impossível resistir, quando a conjuração dos preconceitos de casta ou dos interesses familiares é materialmente mais forte, a união entre os dois seres se realiza pela morte, cuja ideia atravessa todo o processo da existência. (COUTINHO, 2004, p. 304)
\end{abstract}

As contundentes palavras do crítico se ajustam muito bem ao caso aqui analisado, visto que a história dos dois personagens apresenta aquele perfil traçado acima. Giorgia e Artur também possuem uma paixão resistente aos anos de separação, também tiveram as vidas cortadas tragicamente pela fatalidade e foram submetidos a situações desesperadas e ao sofrimento, também eles tinham o peso do preconceito social, e, por fim, também optaram pela última das fugas românticas, a morte. E é sobre este eixo temático que vamos nos ocupar agora. Nas duas narrativas há exatamente quatro mortes, das quais duas acabamos de falar: o suicídio de Giorgia e Artur. As outras duas mantêm entre si uma íntima ligação, pois retomam de forma brilhante um motivo já tratado aqui: a agnição. Esse é o aditivo a que nos referimos anteriormente, porque dá aos atos dos personagens uma sobrecarga de dramaticidade. A primeira morte vem, literalmente, pelas mãos de Johann, que depois de ter desonrado a noiva daquele que ele imaginara haver matado, ao sair da casa depara-se com um homem cuja voz achou conhecida, mas ele ignora o cumprimento e segue:

Não respondi: o caso era singular. Continuei a descer, o vulto acompanhou-me. Quando chegamos à porta vi luzir a folha de uma faca. Fiz um movimento e a lâmina resvalou-me no ombro. A luta fez-se terrível na escuridão. (...).

O punhal escapou-lhe das mãos, perdeu-se no escuro: subjuguei-o. Era um quadro infernal, um homem na escuridão abafando a boca do outro com a mão, sufocando-lhe a garganta com o joelho, e a outra mão a tatear na sombra procurando um ferro. 
Nessa ocasião senti uma dor horrível: frio e dor me correram pela mão. O homem morrera sufocado, e na agonia me enterrava os dentes pela carne. Foi a custo que desprendi a mão sangüenta e descarnada da boca do cadáver. (NT, p. 130-131)

Depois de matar o homem, Johann procura uma luz qualquer para poder ver a face do morto. Nesse momento da narração, o narrador onisciente interrompe a história para descrever a pertubação que tomou conta do personagem: o medo que lhe contraiu a face, os dentes que se batiam e batiam no copo levado à boca, tudo em virtude do que fizera. Essa descrição vem aumentar a tensão do conteúdo a ser exposto logo em seguida pelo protagonista: "Aquele homem - sabei-lo! era do sangue do meu sangue... era filho das entranhas de minha mãe como eu... era meu irmão" (NT, p. 132). O homem não nominado, que viera vingar a desonra da irmã, acabou assassinato pelo próprio irmão, Johann. Este, sente-se um maldito, pois praticara incesto e fratricídio numa única noite. Em vingança a esses dois atos é que se dá o assassinato em “Último beijo de amor”. A vítima portanto é Johann, e o algoz é Giorgia, sua irmã. Com uma aparência que, como já falamos, se assemelha à imagem da morte com sua foice, ela entra na taverna com uma lanterna à procura daquele que receberá a punição:

\footnotetext{
Quando a luz bateu em Arnold, ajoelhou-se. Quis dar-lhe um beijo, alongou os lábios... Mas uma idéia a susteve. Ergueu-se. Quando chegou a Johann, que dormia, um riso embranqueceu-lhe os beiços: o olhar tornou-se-lhe sombrio. Abaixou-se junto dele, depôs a lâmpada no chão. O lume baço da lanterna dando nas roupas dela espalhava sombra sobre Johann. A fronte da mulher pendeu e sua mão passou na garganta dele. Um soluço rouco e sufocado ofegou daí. A desconhecida levantou-se. Tremia, e ao segurar na lanterna ressoou-lhe na mão um ferro... Era um punhal... Atirou-o no chão. Viu que tinha as mãos vermelhas - enxugou-as nos longos cabelos de Johann... (NT, p. 136-137)
}

Se na narrativa anterior, até mesmo para se manter o devido suspense, Giorgia é uma personagem sem expressão, aqui é ela quem confere ao conto o vezo macabro de todo o livro: é uma verdadeira mulher fatal, cruel e assassina. Diferentemente das outras narrativas, nas quais a morte é reservada àqueles e àquelas que cruzam o caminho dos celerados azevedianos, no último conto e só nele, um desses celerados também morre. E morre pelas mãos de uma mulher, algo que merece ser destacado. Esses dois fatos constituem dois elementos de ruptura com o que podemos chamar de o ponto de vista do livro. Estruturado tematicamente em cima de histórias pessoais de personagens masculinos, essa última narrativa muda o pólo de energia ao fazer de uma mulher a assassina do próprio irmão; sua ação mortal não deve nada aos personagens sádicos masculinos: atente-se para o detalhe do sorriso e do olhar sombrio ao ver a vítima, e principalmente, o enxurgar das mãos ensanguentadas nos cabelos do irmão. 


\title{
Considerações finais
}

Como ficou nítido, a figura da mulher, a morte e o amor formam uma tríada estrutural dentro de Noite na taverna, compondo, juntamente com outros elementos como a figura do homem fatal, a estrutura de sentido básica sobre a qual se assentam todas as narrativas. Como também ficou demonstrado, os três elementos estão intimamente ligados, pois, de uma forma ou de outra, um enseja o aparecimento do outro.

Uma crítica que cabe à obra e ao autor, relaciona-se aos motivos românticos aqui expostos e sua relação com a realidade nacional. Álvares de Azevedo importou os motivos da literatura europeia, isso não é um problema e não desmerece a obra. Porém, o autor não se preocupou em dar-lhes uma feição nacional, preferindo copiar também a forma, como fica evidente no uso de nomes europeus, na ausência de uma ambientação nacional, etc. Noite de taverna é toda voltada para a Europa: as motivações gerais, os nomes dos personagens e cenários das ações, tudo tem como pano de fundo o horizonte europeu.

Além disso, a obra se filia integralmente ao mal-do-século, e, espelhada nas obras "malditas" de autores europeus, não é somente constituída de histórias transgressoras da moral burguesa, mas também toca o terreno do macabro e do satânico. Resultado disso é a posição completamente marginal dessa obra na história literária nacional, já que ela se distancia do restante da prosa romântica nacional pelo fato de esta ter retratado a realidade brasileira com relativa fidelidade. Esse livro de contos deve ser visto como um elo de ligação de nossas letras com toda uma tendência que produziu excelentes obras na literatura europeia do mesmo período, constituindo-se um livro sem precedentes na literatura brasileira.

\section{THE MACABRE TRIAD OF NOITE NA TAVERNA: WOMAN, LOVE, AND DEATH}

\begin{abstract}
This text has as its corpus the work Noite na taverna, by the writer Álvares de Azevedo, one of the greatest writers of Brazilian Romanticism. The focus of the analysis is the relationship between three recurring elements throughout the work, namely, the figure of the woman, love and death, showing that the three are intrinsically linked in the work, whose influence of European romantic literature is also pointed out. For this, our main theoretical and critical interlocutor is the Italian Mario Praz, from his book The flesh, death and the devil in romantic literature.
\end{abstract}

KEYWORDS: Romanticism; Álvares de Azevedo; Woman; Love; Death.

\section{REFERÊNCIAS}

AZEVEDO, Álvares de. Noite na taverna. Rio de Janeiro: Expressão e Cultura, 2001.

CANDIDO, Antonio. Formação da literatura brasileira: momentos decisivos. 5. ed. Belo Horizonte, Ed. Itatiaia. São Paulo, Ed. da Universidade de São Paulo, 1975. (2º volume: 18361880). 
COUTINHO, Afrânio (dir.). COUTINHO, Eduardo de Faria (co-dir.). A Literatura no Brasil. 7. ed. rev. e atual. São Paulo: Global, 2004. vol. III.

PRAZ, Mario. A carne, a morte e o diabo na literatura romântica. Tradução: Philadelpho Menezes. Campinas, SP: Editora da UNICAMP, 1996.

Recebido em: 27/03/2021.

Aprovado em: 02/06/2021. 